\title{
TIMBER DISPOSAL REGULATIONS IN CANADA IN RELATION TO FOREST MANAGEMENT
}

\author{
By
}

\author{
By J. R. Dickson, \\ Dominion Forest Service
}

\section{I-HISTORICAL REVIEW}

$\mathrm{N}$ a consideration of the historical aspects of this very broad subject, nothing would be easier than to confuse the main point in a mass of details. I shall attempt to avoid this pitfall by briefly tracing the development of forest administrative policy in its main objectives and methods.

To begin with, the period prior to the year 1800 may be disregarded, as commercial lumbering had not as yet begun. Lumbering as an important industry in Canada, really began with the issuance of Napoleon's "Berlin decree" in 1806, which almost overnight, as it were, shut off Britain's imports of timber from the Baltic and forced her to look to Canada for supplies. The very next year marked the birth of our "license" system of timber disposal. The several timber "licenses" granted in London in 1807 were the first of their kind to be issued under British rule relative to the cutting of timber on Crown lands in Canada. However, it was not until 1826 that such licenses were offered to the Canadian public and made to yield a revenue.

This important key year of 1807 , therefore, really marks the start of Canada's square timber industry upon commercial lines, for 20 years thereafter much of this timber was cut in trespass. You will note, therefore, that the corner-stone of our timber disposal structure, namely, the sale merely of cutting rights and not of the land, is definitely of British origin. This policy has been well maintained, so that to-day some 90 per cent of the forest land of Canada remains in public ownership.

In 1826 the British Government proposed a system of diameter-limit control for all cutting operations in Canada, but it was disregarded at that time, and this method was not actually applied until 1871, in the case of certain Ontario licenses, and until 1888 in Quebec.

The competitive system of disposing of timber'cutting privileges originated in New Brunswick in 1827 and was adopted in Ontario and Quebec in 1841. In 1849 the first Crown Timber Act in Canada was passed at Toronto by the Parliament of Upper and Lower Canada, and from it most of our present methods have gradually evolved. During the fifties, several important revisions of this Act were made, notably; to provide for the collection of ground 
rent; to accord berth-holders in good standing a preferred right of renewal; and to empower a government to change at discretion any provision of a license, thus ensuring that it conveyed no vested rights. The next key year was 1867 , when the B. N. A. Act accorded each separate province exclusive control over "the management and sale of public lands, and of the timber and wood thereon."

$U_{p}$ to the year 1869 the payment of Crown dues or royalty on saw timber in Canada, was made on the number of cubic feet produced, but in that year Ontario adopted the board foot unit of measurement and by 1880 its use had become general. Since that date, with respect to sawlogs, returns have been made in board feet either on the actual output of sawn material or by one or other of the various log rules in use. With respect to pulpwood material, the situation in Eastern Canada to-day is that the measurement of pulpwood has become a more important matter than the scaling of logs. Yet here again, nearly every province has its own peculiar method of procedure, and the fact that a uniform, standard cubic unit of measure has not as yet been evolved makes for a confusing and unsatisfactory situation. Recently, New Brunswick has taken the progressive step of providing for the volume measurement of pulpwood in cords.

\section{Crown Dues}

Ever since the 1867, as the value of standing timber continued to rise and public interest demanded that each government should receive a proper share of this increase, the schedules of Crown dues in effect have been again and again reconsidered and advanced, (save for occasional temporary decreases in times of depression, such as we are just passing through). It is a significant fact that while during the past hundred years the various forest authorities in Canada have tried out almost every plan of forest revenue finance, the tendency has been gradually toward the adoption of one, uniform method of timber disposal and revenue collection therefrom. After a century of experiments, the disposal of timber by auction or tender after due advertisement--free competition being based on the highest bona fide bid per product-unit, over an upset price-is to-day with one or two exceptions the universal practice throughout Canada. Broadly, the Crown-dues system comprehends the public as the predominant partner in the work of forest management, and this long-time aspect must be kept quite as clearly in view as the more immediate one of revenue collection. To sum up, the Crown dues or Royalties system of timber disposal is inherently adapted to secure under governmental supervision a satisfactory measure of co-operation among all the interests concerned, in the two vitally important matters of forest 
protection and forest renewal, thus safe-guarding the future of the woodusing industries.

Of prime importance because of its reaction on forest administration, was the idea of land settlement which held sway in Canada until almost the close of the last century. That idea was to dispose of all the saleable timber for cash before turning over the land with its timber residue to be converted into farms. Even when the diameter-limit method of control came into vogue, it was not prompted by any plan of forest perpetuation, but was primarily to reserve some timber for settlers' use. It appears to have been the peculiar opinion of woodsmen in these early days that a new forest of value would not flourish on land from which an original stand had been cut, even if it could be protected from fire. Having this idea, no one regarded lumbering as a permanent industry. This general and deplorable failure to draw the necessary line between farm soils and forest soils, has all down the years brought in its train a nemesis of incredible friction, suffering and loss. It explains the lack in earlier years of any well-considered and co-ordinated land-use policy in this country. It has been one of the chief obstructions to the development of forestry in Canada.

Nevertheless, with the meeting of the American Forestry Association here in Montreal in 1882, the seeds of the gospel of forestry slowly began to take root and grow. Suffice to say, that as the net result of many educative agencies during the intervening fifty years, public ideas on forestry have gradually been evolved and clarified. To-day there is widespread recognition of the long ignored truth that absolute forest land must be reserved and dedicated to forestry use, under long-time management plans, in order to ensure in turn, maximum farmland productivity, abundant raw material for the forest industries, uniform stream flow for power purposes, and all the other intangible but essential forest benefits.

\section{II-BRIEF COMPARATIVE STATEMENT OF EXISTDNG TIMBER CUTTING LAWS AND REGULATIONS UNDER EACH FOREST AUTHORITY DN CANADA.}

To-day, each province in Canada, save Prince Edward Island, has an organized Forest Service and controls all matters affecting forest utilization on its Crown lands. In the federal feld, the Canadian National Parks Branch and the Dominion Lands Administration of the Department of the Interior, and also the Department of Indian Affairs, are charged with forest administrative duties. For purposes of comparison, the general procedure followed by each in disposing of timber-cutting privileges having regard to sale, tenure, price, measurement and cutting conditions, may be briefly summarized as follows: 


\section{Nova ScotIA}

Basis of Competition: Non-competitive, sold to first applicant at forty cents per acre, plus the fixed Crown dues as cut.

Nature of 'I enure: An annual, renewable license.

Schedule of Crown Dues: Uniform stumpage dues of $\$ 1.00$ per cord or $\$ 2.00$ per $M$. for all species.

Cutting Regulations: (Authorized under "Land Tax Act" and "Lands and Forests Act," with revisions thereto.) Flexible 10-inch diameter limit control, for all species.

Measurement: Scaling methods-no statutory log rule, but New Brunswick rule used in all government scaling.

\section{New BRunswick}

Basis of Competition: Sale by public auction to the highest bidder over a fixed upset price of $\$ 20$ per square mile, plus the current Crown dues.

Nature of Tenure: Sawmill, pulp and paper, or Crown timber licenses, with right of annual renewal for fixed period ending in 1963 where mill involved, and in 1943 where not.

Schedule of Crown Dues: Yearly revised schedule of prices, as shown in the annually published Timber Regulations. Pulpwood now scaled and sold by the cord instead of in board feet, as heretofore.

Cutting Regulations: (Governed by Forest Service Act of 1927, with its revisions.) Diameter-limit control by fixed stump and top diameter limits, both inside bark, for each species, with special permits to cover muskeg or other abnormal or submarginal stands. Lower limbs to be lopped. Penalty of twenty-five cents per undersized tree cut, or stump over 16 inches high, and of $\$ 5.00$ per $M$. for timber wasted or wrongly left.

Measurement: New Brunswick log rule statutory. Inspection of cutting by scalers at intervals.

Note: A Forestry Advisory Commission, created in 1927, may be called on to advise the government in forestry matters.

\section{QUEBEC}

Basis of Competition: The right to cut is sold by public auction, usually after one month's advertising. The government fixes a so-called "Price of Adjudication" per square mile for each block offered, and bidding is based on an upset price per product unit, over and above the current schedule of Crown dues.

Nature of Tenure: An annual license, renewable as long as timber remains 
and rules are observed, and the land is not required for other purposes. A "Special License" to cut up to 150,000 board feet is also issued.

Schedule of Crown Dues: An emergency schedule adopted in 1930 now prevails and will remain in force till May 1, 1935, unless in the meantime the old regular rate of prices be restored by Order in Council. The present policy is to revise the Crown dues schedule yearly, instead of each ten years as in the past. A list giving the Crown dues currently in effect, appears from time to time.

Cutting Regulations: (Authorized by the "Lands and Forests" Act of 1925 and amendments thereto.) Control of cutting is partly by the old, species, diameter-limit system and in part-where the licensee is "Cutting by Exception"--by means of a provisional working plan. In latter case the licensee submits a cutting plan three to six months in advance of felling. The area is then jointly examined by the government and company foresters who decide on the ground, the appropriate cutting conditions. In such case the cut, in effect, is limited to 80 per cent of the annual growth. Low stumps and minimum waste are insisted upon. A triple inspection of woods operations as cutting proceeds is provided by the local ranger, Inspector and Forest Engineer.

Measurement: The Quebec Log Rule is official.

Note: In 1931 a Forest Products Commission was created to devise methods of improving the forest industries, and to advise with the Govern. ment generally. Also, the Timber Industries Association may be called into consultation.

\section{ONTARIO}

Basis of Competition: Timber is disposed of by competitive tender after advertisement for two to three months. Successful tenderer is the one offering highest bonus on a product-unit basis, over the existing Crown dues plus usually an additional upset price.

Nature of Tenure: An annual license, renewable-if conditions observed. (One license has been renewed yearly ever since 1846).

Schedule of Crown Dues: Much modified during current depression. Published at intervals and available on request. Normally subject to revision about every five years.

Cutting Regulations: Through the broad enabling legislation of 1928 and 1929 (namely the "Timber Cutting Regulation Act" and the "Pulpwood Conservation Act"), the Minister of Lands and Forests now holds the most complete power to fix at his discretion all the cutting conditions on each 
timber or pulpwood operation. It is understood such action is planned as and when provisional working plans are framed and approved.

Meantime diameter-limit control of cutting, by separate species, is being applied under the Timber Administration Branch, as authorized by the "Crown Timber Act" of 1869 and amendments thereto. Disposal of slash is required about camps, dumps, along tote roads, and in other areas of high hazard. All cutting must be done without waste.

Measurement: The Doyle Log Rule is official.

Note: In 1927 the "Provincial Forestry Board" was created to study forest problems and advise the government in reference thereto.

\section{ManitoBa}

Basis of Competition: By public auction after advertisement for at least thirty days.

Nature of Tenure: Either an annual timber sale contract with not over five years limit, or a renewable annual license having a fifteen year limit.

Schedule of Crousn Dues: As per list of prices published in Manitoba Gazette of October 21, 1933. Certain changes were made at this time.

Cutting Regulations: (Authorized under the "Forest Act" of 1930 and revisions thereof.) Control of cutting on licensed berths, is by 10 -inch diameter limit at 18 inches from ground, and on timber sales by marking or otherwise designating.

All merchantable wood to be taken with no unnecessary damage or waste. Stump height, 12 to 18 inches. All debris to be piled and burned unless otherwise stated.

Measurement: Clark's International Log Rule, official.

\section{SASKATCHEWAN}

Basis of Competition: Sale by public tender after thirty days' advertising.

Nature of Tenure: Same as Manitoba.

Schedule of Crown Dues: Same as Manitoba schedule, except for some minor changes. List available at Department of Natural Resources, Regina.

Cutting Regulations: (Authorized under "The Forest Act" of 1931 and subsequent amendments.)

The list of cutting regulations is identical with that in force in Manitoba-both being adopted with little change from the former Dominion Forest Reserves regulations.

Measurement: Clark's International Log Rule, official. 
Alberta

Basis of Competition: By public tender after due advertisement.

Nature of Tenure: An annual, renewable license; an annual Permit Berth, renewable up to a three-year limit; or a non'competitive, limited Timber Sale, renewable for one year only.

Schedule of Crown Dues: An elaborate schedule of dues has been established both for licenses and permit berths and these are available on application to the Director of Forests, Education.

Cutting Regulations: (Authorized under "The Provincial Lands Act," and "The Alberta Forest Reserves Act," with subsequent amendments.) Two sets of regulations are in use; $i$. e., inside and outside forest reserves.

Timber cutting on limits is controlled by a 6 -inch diameter limit. All timber fit for use to be taken under penalties. All debris shall be disposed of in accordance with the directions of the proper forest officer.

Measurement: The Modified Scribner Log Rule is the official rule for government scaling. Saw-mill operators must report board foot content of sawn output.

\section{Brttish Columbia}

Basis of Competition: Sale by tender or open public auction, after advertisement of one to eight weeks.

Nature of Tenure: One year timber sale; renewable to definite date set in contract. Also a one year hand logger's license, non-competitive.

Schedule of Crown Dues: Is quite complicated. See Part 7 of the "Forest Act" with its amendments to date.

Cutting Regulations: (Authorized under the "Forest Act" of 1912, with subsequent amendments thereto.)

Cutting is controlled by a very complete but flexible set of special logging conditions inserted in each timber sale contract, to be strictly carried out under the supervision of the local forest officer in charge. Only timber marked or otherwise designated by the forest officer shall be cut. Desired seed trees or groups of seed trees may be reserved. Reserved trees damaged to be paid for at rate of $\$ 5.00$ per tree. So far as practicable all branches of a logging operation to keep pace with one another. Timber wasted or wrongly left, to be scaled and paid for by operator. All debris to be burned or otherwise disposed of as directed.

Measurement: British Columbia Log Rule is statutory.

Note: The Timber Industries Council is at times called into consultation by the Department of Lands and Forests. 


\section{Government of Canada}

(a) National Parks Branch, Department of the Interior Area administered: approximately 30,000 square miles.

Cutting Regulations: (Authorized under the "Forest Reserves and Parks Act" of 1911 with its revisions.)

In general only dead, diseased and fallen timber is disposed of. No green timber sold unless its removal is required in best interests of the park. All cutting directly controlled by park warden. Slash usually piled and burned.

(b) Dominion Lands Administration, Department of the Interior Area administered: approximately 1,500,000 square miles.

Cutting Regulations: (Authorized under the "Crown Timber Act" and amendments.)

Permits granted for square mile berths. Trees to be cut and used without waste, and all debris either scattered or burned.

In this area there is estimated to be about 60,000 square miles of timber forest.

(c) Department of Indian Affairs

Area administered: approximately 8,000 square miles.

Cutting Regulations: (Authorized by the "Indian Act" of 1923 with later amendments.)

Timber disposed of by public auction or tender under an annual, renewable license. Diameter-limit control of cutting. All debris to be disposed of as required and no waste permitted.

Log rule of each province is used on Indian lands within the same.

Of the total area of Indian Lands, about $70 \%$ or 5,600 square miles is wooded.

\section{SUMMARY}

Since the start of the great trade depression in 1929, practically no major change in timber cutting regulations or methods has been effected by any Forest Authority in Canada. Of considerable significance, however, was the adoption of the International $\log$ Rule by two of the Prairie Provinces, and also the vigorous attempt in New Brunswick to encourage the sale of pulp. wood by volume measurement rather than in board feet. Still another change is the new Quebec practice of arranging logging inspection so as to fully coincide with the actual cutting, i.e., during the fall months, while felling is under way.

In comparing this array of Crown timber regulations all across Canada, 
three important governing principles will be noticed as being all but universal and in accord with good forestry and good business. These are:

(a) Sale of timber cutting privileges only under permit, timber sale, or license, and not of the forest land itself.

(b) Free public competition by auction or tender, with acceptance of highest bona fide bid.

(c) General adoption of the product-unit as the essential basis of competition.

It will be observed that nearly every province has a log rule of its own. To what extent, if any, these varying methods might be standardized is an interesting question. Should the metric system be adopted in Canada in the not distant future, cubic measurement of timber may become general, so that a standard all-Canada cubic log rule, based on the metric system, is among the possibilities.

\section{III-APPARENT CAUSES OF EXISTING GAP BETWEEN THE CUTTING REGULATIONS ON PAPER AND THEIR ACTUAL WORKDNG-OUT DN THE WOODS}

There are two or three decided disabilities in the scope of our timber disposal regulations to day. One is the utterly inadequate nature of diameter limit control. Another is what the Chief Forester of Quebec has aptly called the "pernicious" jobbing system, while a third is a lack of thorough, dependable, properly-timed inspection of cutting. Nevertheless, as they stand on paper our controlling laws and regulations seem to afford an adequate basis for the introduction of minimum silvicultural requirements. The trouble is that this basic enabling legislation is not finding expression in silviculture.

It is surely the simple truth to say that in Canada comparatively little has been done as yet toward treating the forest as a crop-a renewable resource. Although nearly everyone concedes the necessity of forestry and desires action, we have not achieved much success as yet in translating theories and regulations into actualities. We continue, as Dr. Fernow wittily put it, "to practice forestry everywhere but in the woods." A few years ago after Sir Roy Robinson, now Chairman of the British Forestry Commission, had crossed Canada, studying our forest situation, he made the following observation: "The present gap in Canada between lumbering practice and sound silviculture appears to be very great." Just one more witness-- that well informed forester, Dr. White of the Toronto School, on his last return from Europe, made this appeal: "We Canadians must change our logging principles. Log. ging in Canada to-day is dictated entirely by consideration of what will give maximum immediate profit. It is not affected by the claims of the forest as 
a crop. We must employ forest management based on correct cutting regulations, honestly administered, in order to increase and fix our acre yields."

Now, there must be one or more fairly good causes for this discouraging situation, and I take it that the raison d'être of this paper and of our ensuing discussion, is a candid attempt to envisage them. Fire protective organization in Canada to-day offers reasonable security for steps toward forest management, and the presence of over 300 trained foresters in the country shows that skilled supervision is not lacking. Why then should there be this open gap between our precept and our practice? Briefly, is it not in the main because vital economic factors are involved that lie beyond the control of any single forest authority in Canada or of all combined, for that matter? Obviously this immediate and powerful cause-operative from coast to coast and far beyond our boundaries-is economic pressure.

Trade competition for markets in the lumber industry has for many years been so searching, relentless and world-wide in scope and the economic "law of the margin" so potent and decisive, that the price which harried private owners, say in Washington or Oregon, will accept for their lumber, cut without regard for the future, absolutely decides how much silviculture the Chief Forester of British Columbia can demand of his licensees without putting them "in the red," or a Quebec operator can afford to practise and still remain solvent. In support of this view let me quote a remark made by a prominent Montreal lumberman not long since. He said: "Unlike many commodities, lumber in Canada is subject to keen competition from the four corners of the world. We have grown accustomed to seeing our local markets demoralized at crucial periods by heavy shipments from the United States and elsewhere."

If these facts mean anything, they surely signify that the forestry problem on this continent has now become a close-knit international one, that ultimately can only be satisfactorily met and dealt with on that broader stage. This thesis is strongly supported by the official action of the Quebec Forest Products Commission, which has recently urged upon Canadian lumber dealers that it is essential for them to co-operate fully with the new Lumber Code Authority of the United States, and also with the lumber merchants of that country if they want to facilitate business and marketing. Some such co-operative sales arrangement probably represents the most practical plan that could be adopted to bring about an approach to the much desired goal of market stabilization.

This matter of a paying market and how it may be attained holds the solution of our pressing economic problem. If in some way the lumber industry in North America could succeed in regulating its output to this end, the 
needs of forestry would be equally served. The fact that the United States and Canada have a common language, with money and standards of measurement almost uniform and their labour and general industrial conditions much the same, should facilitate such a step.

Because of the above noted trend, it is of deep import that under Section 10 of the Lumber Code, the wood-using industries of the United States are now strongly committed to a program of active forest management. On this point Secretary Wallace said recently: "Here, for the first time, the woodusing industries as a group have committed themselves to a policy of conservation and sustained forest production. The next step is to translate this declaration of principles into action in the woods. To do this will require patience and sympathetic co-operation in many thousands of woods operations. We propose to establish practices in woods operations that will safeguard young timber from injury in logging; will prevent unnecessary damage to trees left in the woods, and will promote regeneration of the forests after lumbering."

\section{More Research Needed:}

You will perhaps agree that there is one other important cause for the existing hiatus between forestry precept and practice in Canada. Even if the "economic" lion in the path were removed, the general lack of knowledge regarding the life histories of trees and stands and their reactions to environ. mental conditions, would still remain to confuse and restrain the forest ad. ministrator. He and his staff would to a large extent still be obliged to proceed very cautiously, by trial and error methods, until through the avenue of forest research, the necessary information and tabular data had been secured to serve as a sound basis for long time forest working plans. Forest Research is the one constructive means of solving the many problems which beset the continued productive use of forest land.

The urge for economic research in forestry is even more pressing than the need for the study of silvics. There would seem to be a good field here for close co-operation between the Government and the operator in carrying out experiments to determine the cost and comparative financial advantage of different methods. For instance, we need in Canada detailed time-cost studies in logging practice. One important use for such cost figures is to demonstrate what trees in a stand may be most profitably taken in a selective cutting. All too frequently at present, a surprising amount of valuable advance growth is being cut at a direct loss to the operator. The point is that careful cost-keeping data would serve here and in other phases of utilization as well, to guide the operator toward the procedure likely to give him the maximum financial 
returns compatible with keeping the forest on a permanently productive basis. The Position of the Canadian Society of Forest Engineers

In his stirring and thought-provoking article in the last Chronicle, on the need for a "Society Program," Mr. Avery points out that one of the charter objects of this Society is the promotion of the broad interests of forestry in Canada. Surely nothing could mark with more dignity and promise the silver anniversary of our founding in this very City, than to get behind some considered plan or program of action and work to close that decided gap between forestry precept and forest practice in Canada.

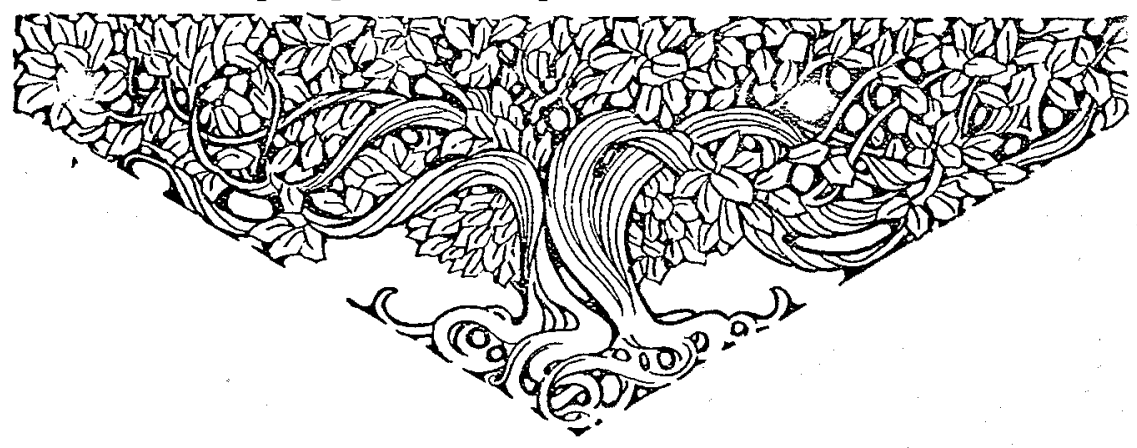

